\title{
Common steps. A prototype for urban landscape regeneration
}

\author{
Salome Katamadze \\ Dipartimento di Architettura, Università degli Studi di Ferrara, Italia \\ salome.katamadze@edu.unife.it
}

\section{Duccio Fantoni}

Dipartimento di Architettura, Università degli Studi di Ferrara, Italia duccio.fantoni@edu.unife.it

\begin{abstract}
La ricerca affronta le difficoltà nel definire la città con la dicotomia di spazi pubblici e privati in quanto queste categorie risultano spesso ambigue in termini di uso dello spazio, proprietà del suolo e delimitazioni. Questi fenomeni urbani di incertezza si manifestano intensamente nei paesi post-Sovietici dopo il drastico passaggio da sistema socialista a privatizzazioni, generando processi urbani spontanei e incontrollati.

Lo studio si concentra su Tbilisi, capitale della Georgia, in cui, attraverso l'elaborazione di progetti site-specific per frammenti urbani abbandonati, si è trovata l'opportunità per riflettere sul ruolo dello spazio pubblico nella città contemporanea. Le contraddizioni delle città post-Sovietiche hanno evidenziato l'impossibilità di elaborare strategie su vasta scala. Per questo la ricerca affronta le trasformazioni urbane secondo strategie puntuali. II progetto è stato sviluppato nella cornice della Biennale di Architettura di Tbilisi 2020 sul tema del Commonness.
\end{abstract}

\section{Parole chiave}

Infrastruttura, riappropriazione sociale, prototipo architettonico, paesaggio, città post-Sovietiche, scale urbane, rigenerazione urbana

\begin{abstract}
The research concentrates on the difficulties of defining a city by the dichotomy of public and private spaces, as these categories are often ambiguous in terms of use of space, land property and limits. These urban phenomena of uncertainty have been significantly increased after the drastic switch from socialism to privatization in the post-Soviet countries, afterwards resulting as a spontaneous and uncontrolled urban tissue.

The study focuses on the capital of Ceorgia, Tbilisi, where, by developing site-specific projects for the neglected urban fragments, finds the opportunity to reflect on the role of public space in the contemporary city. The contradictions of a post-Soviet city demonstrate the difficulties to operate with large scale actions. However, it still suggests the possibility to modify the urban condition through punctual interventions. The architectural proposal has been developed in the frameworks of Tbilisi Architecture Biennial 2020 on the topic of Commonness.
\end{abstract}

\section{Keywords}

Infrastructure, social re-appropriation, architectural prototype, landscape, post-Soviet cities, urban stairway, urban regeneration 


\section{Premises}

During the '90s, the shift from a socialist system to a capitalist society affected every aspect of the former Soviet Republics. On the background of the whole system's collapse, the most rapid changes were evident in the spontaneous transformation of the city structures and conformations. In particular, the city of Tbilisi is an emblematic example of this metamorphosis, one of the most important Soviet metropolises and the main city of the Transcaucasian area.

Tbilisi is the capital of Ceorgia and concentrates 30\% of its population. Because of its origin and morphology, the city follows the river Mtkvari and the rich hilly topography of the territory. During the Soviet period, the original built-up area stretched and the population achieved its maximum, approximately 1.25 million people. During these years the city's urban structure has been decentralized by the population growth and economic development, statistically, around 10000 people per hectare in 1933, which caused a serious demand for more dwellings, as much as from the beginning of $20^{\text {th }}$ century Tbilisi's housing was containing mostly one-store $(62,2 \%)$ or two-store $(29,1 \%)$ in quite chaotic building systems. In fact, before 1934 there was no official documentation that would provide any guidelines for the city's expansion. Only in 1934, there appears the first advanced masterplan of Tbilisi, which was followed by the second one in 1951 and later after Khrushchev's Micro-rayon system enlargement came the third in 1970, which should have provided ground rules until the early 2000 s.

$$
\begin{aligned}
& \text { In the } 1960 \text { s after Nikita Khrushchev's Housing Re- } \\
& \text { forms, the residential blocks were not used else- } \\
& \text { where with such a density as in Easter countries. } \\
& \text { This homogenous living block propaganda created a } \\
& \text { type of Soviet City as a genre. In essence, it is a se- } \\
& \text { ries of similar buildings and settlements - the so- } \\
& \text { called "micro-rayon" - which are considered as an } \\
& \text { ideal form for living. (Bakhtadze, 2019, p 76.) }
\end{aligned}
$$

Since, in the beginning, the biggest expansion of the city started by following the banks of the river Mtkvari, all the flat areas were easily urbanized and divided by zones. Indeed, the main characteristics of micro-rayon's were refigured within 4-5 store or 9-16 store buildings with linear road connections and pathways which would link all the public services such as canteens, kindergartens, schools and markets accessible within 500 meters in one complete system serving approximately 11 thousand inhabitants. Additionally, within such an urban arrangement, the green spaces served as a filter between building typologies. However, the principal peculiarity of Soviet planning methodology was not to perceive one single volume but to read architecture within a united complex, that's the rea- 
son why districts fill the territory as autonomous fragments, as they were creating nearly independent neighborhoods, with their facilities and infrastructures. During the high demand for more housing possibilities, the city growth exceeded not only the flat areas but reached as well the hills, modifying approaches towards the context and urban fabric. In the hilly micro-rayons, the architectural approach gains more specific indications, such as higher buildings, not less than 9 storeys, within higher density.

\begin{abstract}
For Georgian cities, which are usually located on difficult terrain, the challenge to try to convert the steep slopes in residential areas was very important. One of the first, very interesting, experiments was the construction of the slope of Nutsubidze Street in Tbilisi (Architects: O. Kalandarishvili, G. Potskhishvili). They used some unconventional solutions: placed typical 9 and 16-storey large-blocks and large-panel houses on a minimal number of sections on difficult terrain and connected them by serpentine motorways. The main sub-movement is smooth and balanced with powerful groups of elevators and covered passages on different levels, designed for the special house-distributions." (Okuashvili, 2011, p. 80)
\end{abstract}

In fact, along with modern infrastructures, such as roads and the subway, the pedestrian path became the most characteristic connective element of the hilly tissue. On one hand, Soviet buildings seem not to interact with the landscape, but that they only base their criteria on the quantity of the inhabitants and constructive necessity. On the other hand, the district's public spaces inevitably adapt to the topography and the steep slopes of the territory. In this scenario, one of the most emblematic and repeated solutions is an urban stairway, which passes throughout the hilly neighborhood of the city and generates a space of connection and sharing, independently from the car roads, relating on-
The study observes the results of the shift of paradigm from a socialist organization of the city to the capitalist model and its current state of crisis. In particular, because of the uncontrolled urbanization during the last 15 years of growth, mainly based on the collapse of societies' notion of "for all or for none!", the current circulation and accessibility are based on car benefit policy, which leads to negligence and lack of investment, and it damages the popularity of alternative connective opportunities. The interesting fact about the context of the post-Soviet republics is that many of the transformations of European cities that occurred in the early post-war period are manifested here under different conditions. The category of capitalist city acquires a different meaning in this context, more ambiguous in individual cases and more extreme in its consequences. Changes in the use of the city and lifestyles have been more abrupt and have profoundly modified the unstable equilibrium of the Soviet period.

The relationship between different urban fragments highlights at the same time the criticality of these changes and the richness of the complex context and coexistences.

These sudden transformations have superimposed in the same place irreconcilable infrastructures with different and sometimes opposite uses. This interweaving generates an overproduction of waste areas, uncertain leftovers of urban development. This ambiguity prevents any formal reading of urban facts but suggests possible scenarios through the re-invention of reality.

As we have seen, the city can be described from an aesthetic-geometric point of view, but also an aesthetic-experiential one. To recognize geography within the supposed chaos of the suburbs, one can have an attempt to enter into a relationship with it using the aesthetic form of the erratic route. What is discovered is a complex system of public spaces that can be traversed without interruption. The voids of the archipelago constitute the last place 
where it is possible to lose oneself within the city, the last place where one can feel out of control and in dilated and extraneous spaces, a spontaneous park that is neither the environmentalist re-proposition of a false rustic nature nor the consumerist exploitation of free time. They are a public space with a nomadic vocation that lives and transforms so quickly that it exceeds the planning rhythms of the administrations.

(Careri, 2006, p. 133, translated by the authors)

In this sense, a key element is land ownership. The privatization of public areas of the city has resulted in the ambiguity of situations in the post-Soviet republics, where private properties host public infrastructure. Urban voids are often the symbol of a stalemate of the agents of transformations. Topographical characteristics represent a further element of difficulty rather than a specific character, slowing down speculation processes but also partly preventing maintenance.

\section{Landscape as the root of the city}

The methodology of the research could be defined as a genealogical approach, in which the tool of the Architectural micro-Project inquiries not just to the current urban factors but also to the pre-existing territorial presence.

Every city exists in a landscape; many natural features could disappear, but the topography usually remains. It is more convenient to adapt to it, rather than to transform it radically.

The research is based on the importance of the relationships among existing elements instead of the theoretical model that should describe the city. The historical systems of organization are relevant in their sense of concision, but not enough to consider the urban conditions. In this sense, on one hand, the issue of public space is related to the rhythm of life, the rule of sociality, and cultural custom: the intangible presence of the city; on the other hand, the physical consistency of urban territory represents a key factor in the definition of communities.
These two aspects are inseparable and weaved together. In fact, of this impasse, the interpretation of the city as a dense field of relation is fundamental. The understanding of urban processes, as a combination of physical factors and cultural aptitudes, requires a multi-scalar approach to the issue of urban spaces. The criticality in a macro-scale could relate to a very specific condition in a micro-scale. Therefore, the research developed a detailed-based strategy to reconnect architectural elements to the dimension of the city. It appears fundamental to replace the abstract scheme of urban tissue with a more human-scale configuration, in order to face this impasse in the complexity of the city.

Usually, disciplines such as geography and landscape are introduced in the study of rural settlements or archaeological study of the ancient cities. However, these aspects rarely influence the interpretation of contemporary cities. This negligence reflects the attitude to study the territory only through modern cartography, the representative approach that has been adopted by military cartography at the beginning of the nineteenth century to eliminate all the non-solid traces from the face of the earth. Without a doubt, this tendency, which today stands for the traditional cartography, caused the reduction of symbols that has excluded many of the landscape elements of the area from the representation and not only. The more ephemeral and less cumbersome elements were the first to be overlooked in favor of the more prominent obstacles such as houses and large trees. In addition, quantitative parameters have replaced qualitative ones. In these processes, the morphological aspects tend to disappear (Farinelli, 2003). Such graphic bias determines the loss of essential characteristics of the city. The attempt to read the urban fabric according to abstract morphological models responds to a quantitative-cartesian logic, which is both extremely effective and unsuccessful. To understand this paradigm correctly, the writings of geogra- 


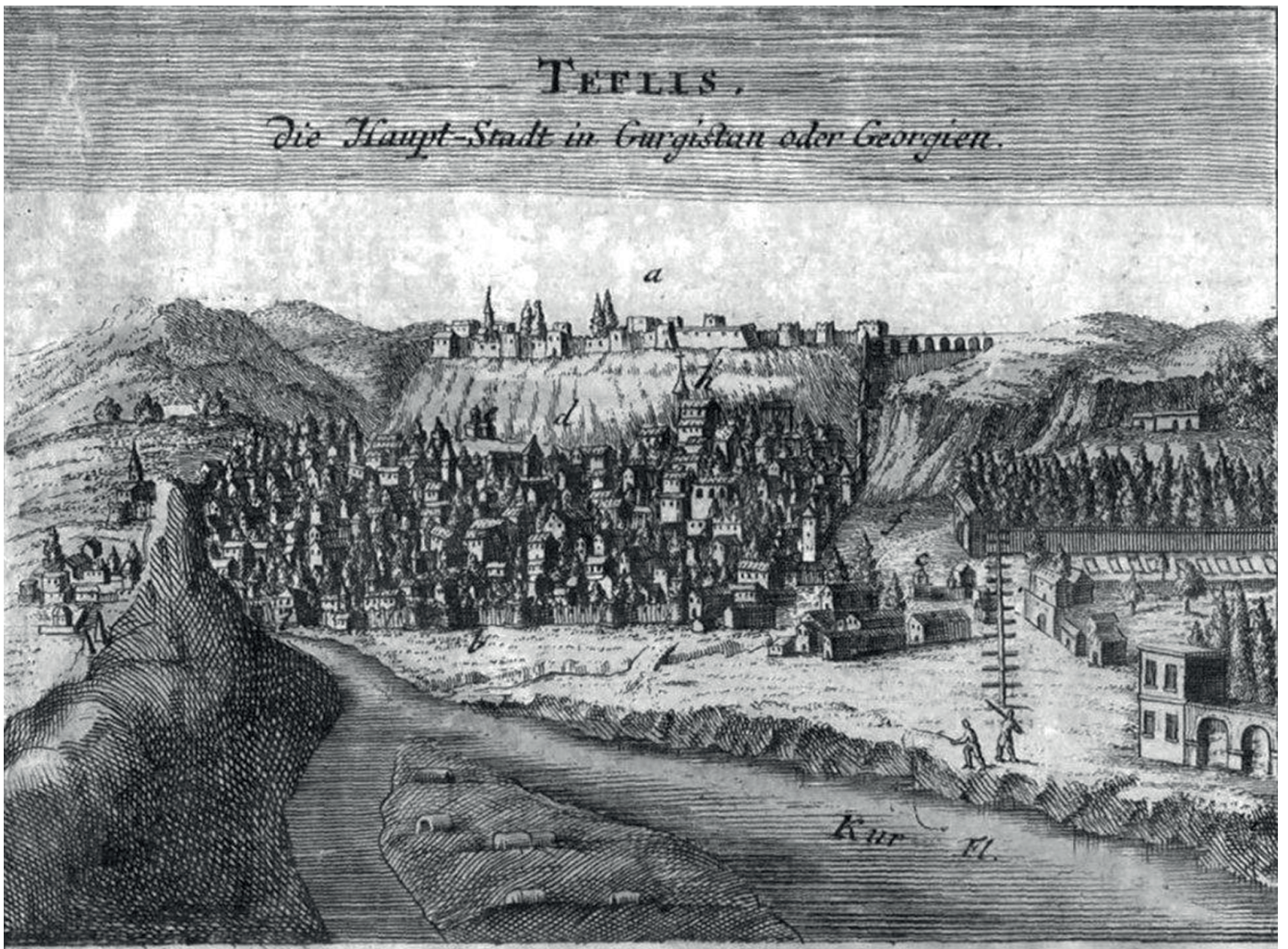

a. Die Veftung. 6. Dre Armen: Haoupt Kinch . c. Catholifche Kirch. d.Capuciner Closter. e. Magazin f. Mufter-Platy. g. Der Marck. h. zum Y.C Veutz, i des Printzen Palaft.

Fig. 1 -Tiflis, Capital of Georgia by Johann Baptist Homann, Nurnberg, 1734. Fonts: wikimediacommons.org 


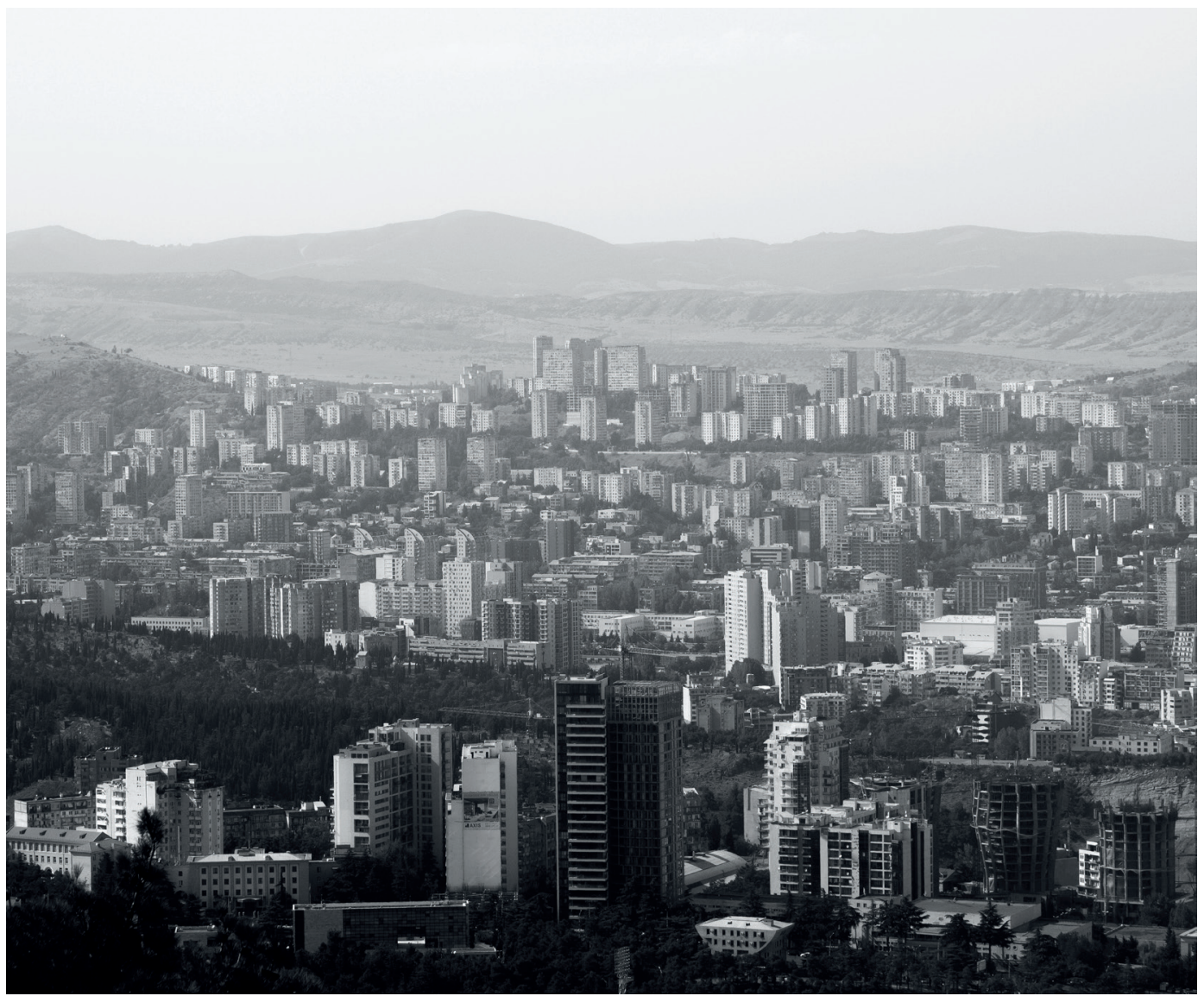

Fig. 2 -Residential building dominating the view on the outskirts of Tbilisi, Georgia. Fonts: unsplash.com (photo: Julian Larcher, 2020) 


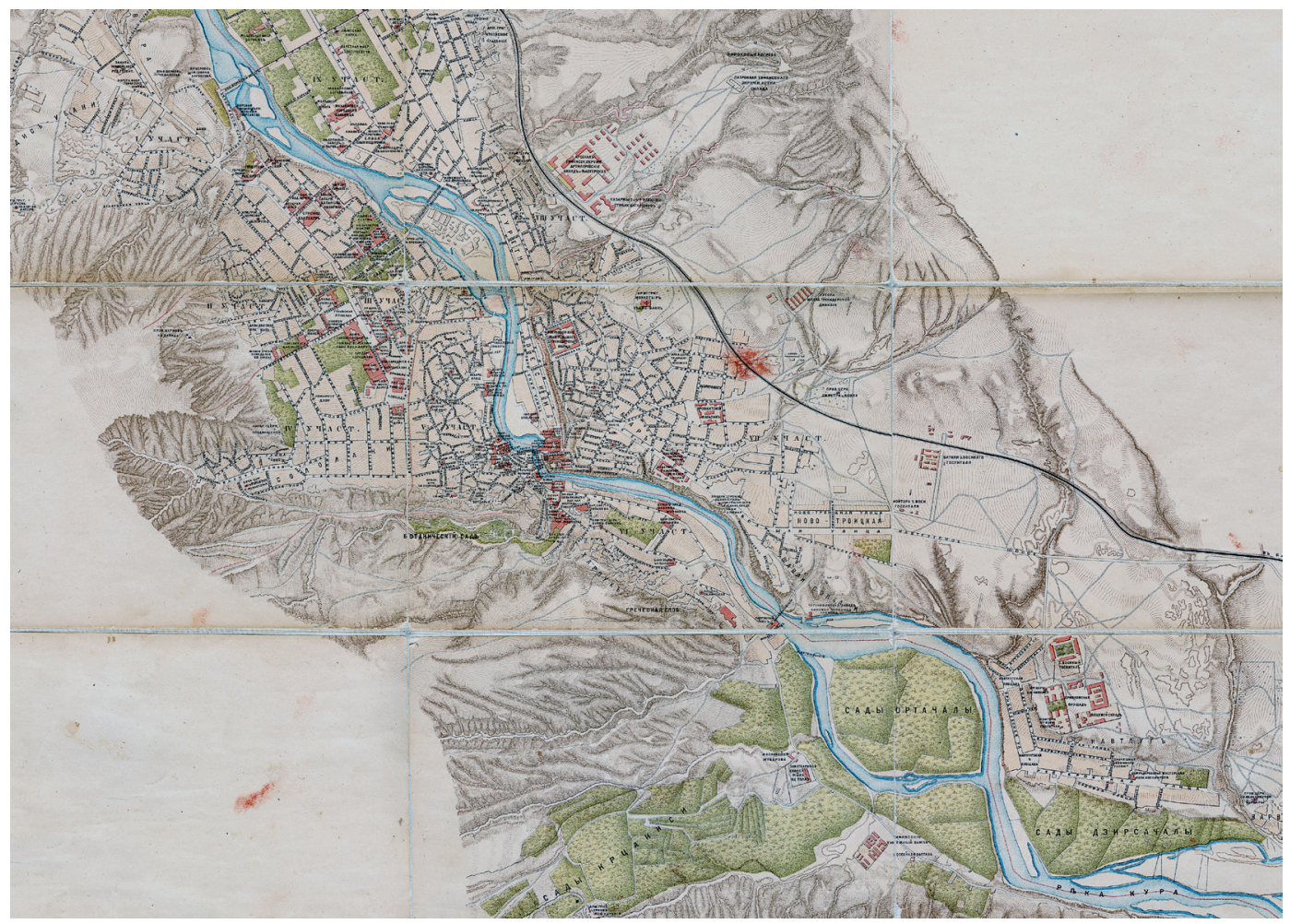

Fig. 3 -Tiflisi city plan with surroundings, created in st. Petersburg by the cartographic office of A. Ilina, 1887. Fonts:mapsland.com 


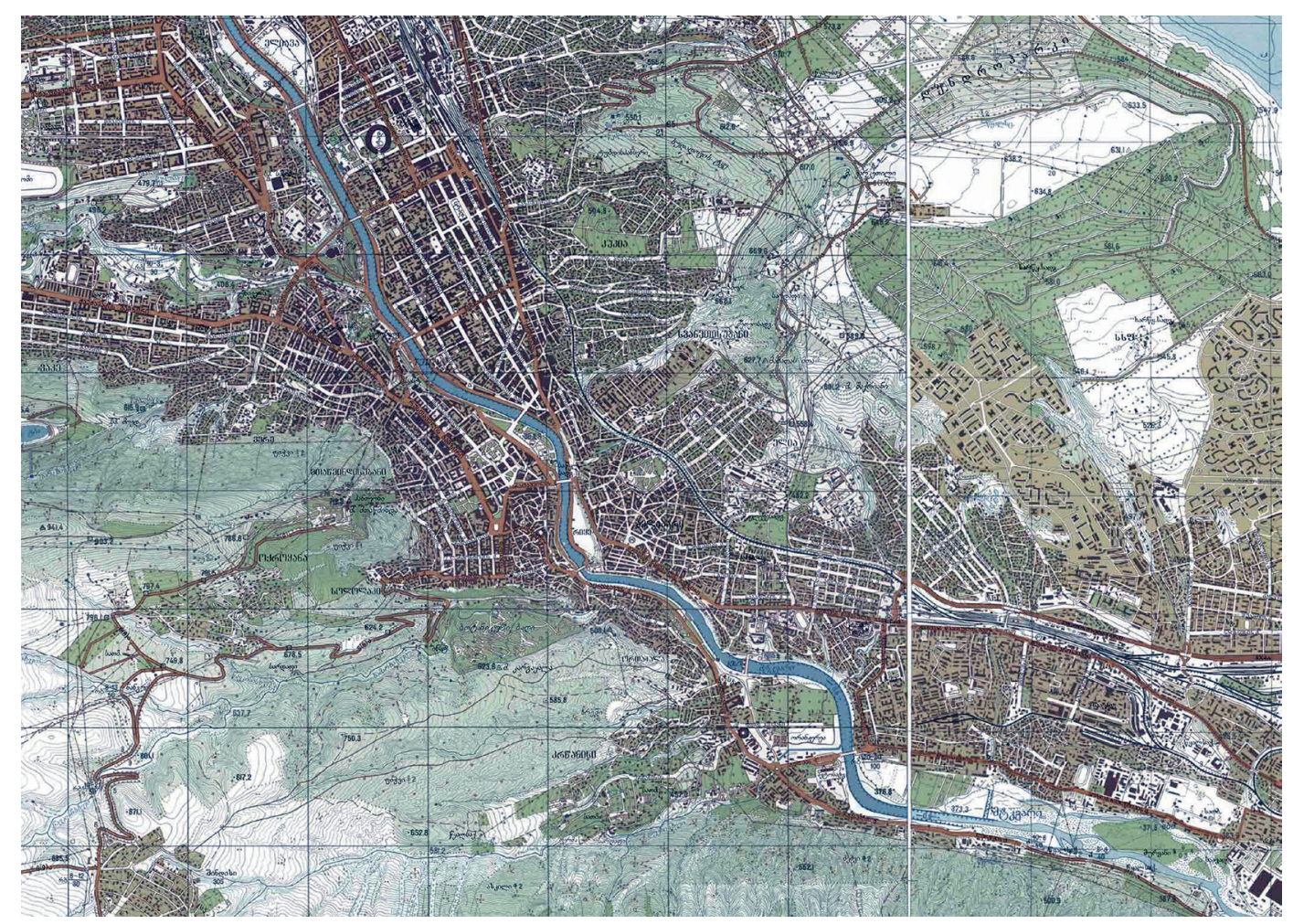

Fig. 4 -Detailed topographic map of Tbilisi, created in Tbilisi, Georgia 1975. Fonts: mapsland.com 
pher Franco Farinelli result to be essential, especially for the re-visitation of the scholastic perception towards spatial and topographical representation. The author strictly divides the definition of the space from the landscape and introduces a sharper definition of the measuring system.

\begin{abstract}
Statistics do nothing but merely translate the topographical idea of settlement into a different language, the language of numbers. They reduce themselves, which is truly a process, to categorize the things, and then distinguish them according to their size, into rural or urban locations. The only difference is that, whereas from a topographical point of view, it is the form that matters, from a statistical point of view, it is the format, i.e. precisely what the form reveals.

(Farinelli, 2003, p. 133, translated by the authors)
\end{abstract}

On this background, the idea of landscape allows us to evade this paradox and image a different perspective on the reality of the city. Even though the urban landscape is elusive and often unreliable (Assunto, 1994), the two categories could not be isolated as irreconcilable entities. On the contrary, the recovery of the idea of landscape, as a genealogical actor in the urban reality, permits us to focus on the multitude of relations that compose the consistency of the city.

\section{The second life of Infrastructures}

The research aims to show the opportunity to reuse important existing infrastructure, in a state of abandonment, taking strongly into consideration the urban fabric and landscape characteristics of the site. The project reveals a new scenario of new public spaces for Tbilisi, based on the traces of the past. Public space is never a mono-functional space; it is a place for possibilities shared by the community, by giving them the potential to engage the urban environment. In this sense, public space is not a generic shared ground, the void among buildings, but chitect G. Vogt expressed in "Landscape as a cabinet of curiosities": "it is clear that public space must be accessible twenty-four hours a day without any controls, without entry charges, and without surveillance." (Vogt, 2015, p.89).

The boundless accessibility of public space is in contrast with the modern urgency of control. Despite the narration of the 90's architects, the case of shopping malls as indoor, air-conditioned, monitored situations, represent a mistaken model of public space, that is still very common in former Soviet Republics. The physical coexistence of circumstances of social interactions and the presence of commercial activities is a common feature of many traditional public spaces. On the contrary, the limited gap of time for accessibility refers to the idea of the hierarchy of uses:

Similarly, those decisions and choices which do not at first produce visible effects act in the same way; we mentioned them at the beginning: timetables, opening and closing times, tariffs, regulations, laws - but also the absence or abolition of laws. They form a context that influences our way of life at least as strongly as visible and concrete things like walls and doors. We call it invisible design to emphasize that decisions of this kind also have a design character and help shape existence. A product of invisible design is the night, the man-made night, a temporal environment open and closed by rules established by man. (Burckhardt L. 2019, p. 176 , translated by the authors)

The invisible design also lies in the processes of transformation that annihilate the possibility of spontaneous and intuitive use of the city. In this perspective, infrastructures are never an innocuous utilitarian endeavor. On the opposite, they mark the condition of use and existence of urban life.

The study case of the Nutsubidze micro-district is emblematic of the crisis of public space in the city of Tbilisi. The neighborhood was built in the Soviet period, in the west part of the city, on the hillside. The dense housing project allowed shaping public space 
into characterized gardens and playgrounds. Currently, part of this green infrastructure is occupied by garages for private vehicles, and the rest remains a low maintenance problem. Despite the issues with the housing blocks, the neighborhood public spaces survive in parallel with the dominant presence of cars, and the reduction of not-build areas. The urban stairs in this case connect the hillside settlements with the downhill ones. It represents an open, quick pathway to reach services absent in the neighborhood faster than one could get by car following long, curved roads. As already mentioned, the Nutsubidze neighborhood follows the micro-rayon typology, where the public services are provided in linear proximity but sparse in reality due to the terracing morphology of the terrain. Because of the new housing buildings, the services become even more overloaded, not to mention commercial spaces in constant expansion, alongside with no additional parking places provided. The stairs allow circular accessibility not only towards originally designed district's functionalities but as well to the aggregated ones, such as the orthodox church, which was built exactly in the connection with the stairs like an island, or the rooftop of the garages, which currently are used as an informal stadium for the morning walks or exercises. The stair seems to accumulate repetitive habits of the residents in very different ways and timings, everyday life rhythm moves around this infrastructural element which somehow remains neglected. It appears emblematic of the fact that the stairs are still public infrastructure but the land on which they are has been privatized. It is for this reason that such a complex condition, where private and public cannot be detached, often generate urban discrepancies. These processes tend to shape fragile "in-between" places, that have no user nor the owner, but only the decayed atmosphere and lost potential of a shared fabric.

The state of such infrastructure manifests the negligence in maintaining this type of route in the op- tics of a city where the preferred mode of transportation remains the car. In fact, the materials of the path have finished their life cycle. The total lack of maintenance makes to disappear completely the trace of this infrastructure. Before being able to intervene on the entire length of the path it is essential to highlight its presence and potential as an element of connection of the neighborhoods. The concentration of housing in multi-story buildings during the Soviet period has allowed freeing public space where at the moment services struggle to survive.

The challenge in these neighborhoods is to bring attention back to those traces that suggest different ways of living. Signaling the presence of an otherwise invisible path requires the precision of appropriate tools, in the scale and especially in the choice of sites.

\section{Common Steps Pavilion}

Within the research framework, the inquiry explores the possibility of a regeneration of an existing fragment of the city through architectural intervention. Nevertheless, the designed approach towards the modifications remains in continuity with the essential landscape aspects and concentrate on bringing forward the main topographical elements of the place as the main result of the project.

The architectural proposal rethinks the relationship between the public stairways and the neighborhood of the Nutsubidze micro-district. This infrastructural element unites not only several slopes of inhabited dwellings, but crosses the main street in several points and hosts on a small terrace the neighborhood church. It is a clear geometrical line that was driven to balance the invasive construction approach towards the existing landscape. Besides aggregating different realities, urban stairs have witnessed various historical periods, during their life cycles this simple element became a symbol of a slow speed connection in comparison with the motorway. 


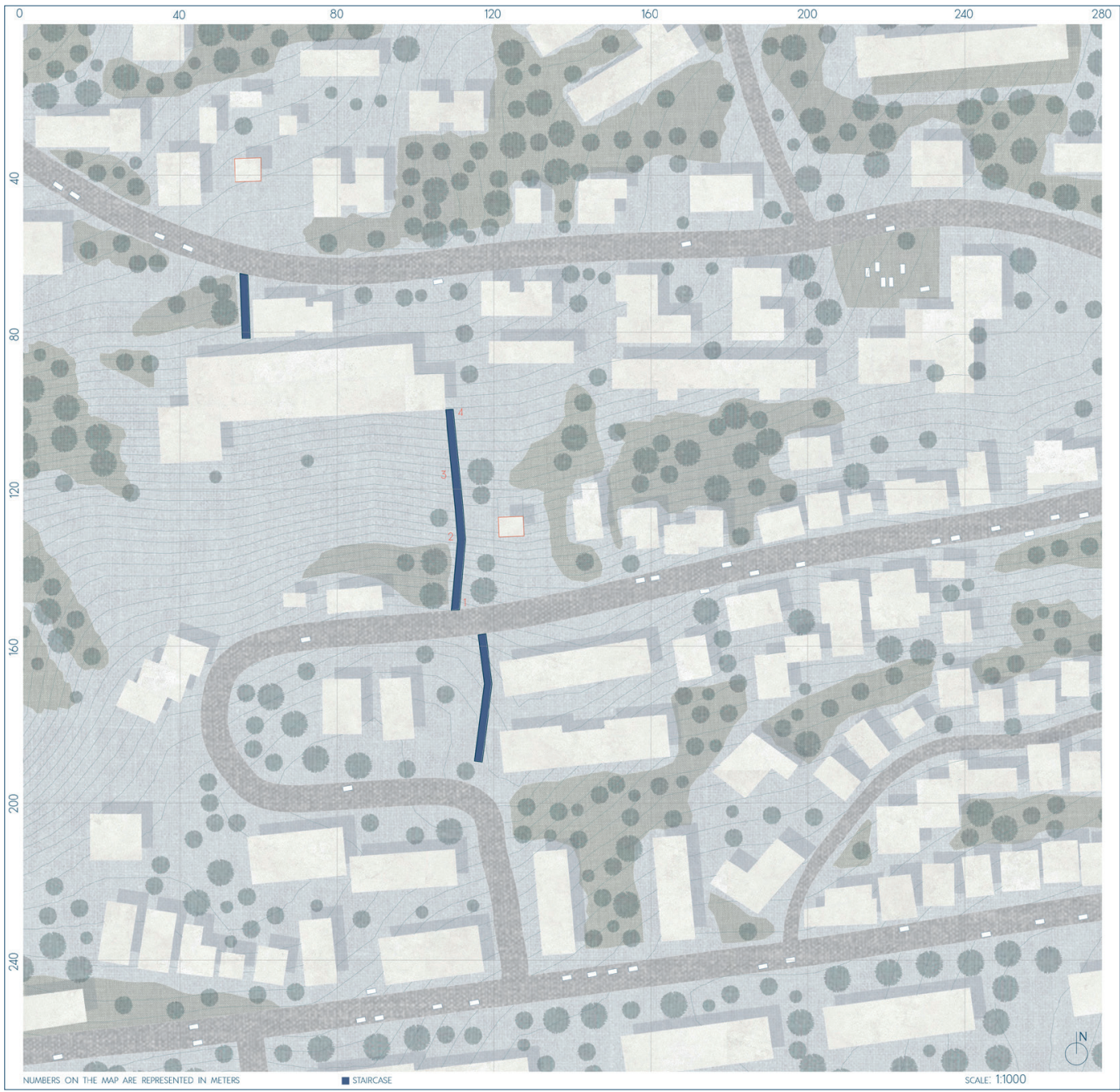

Fig. 5 -Study neighborhood Nutsubidze map

indicating existing infrastructure of urban stairs, their length and how they cut the slopes of the territory. 2020 (Author copyrights: NOIA practice) 

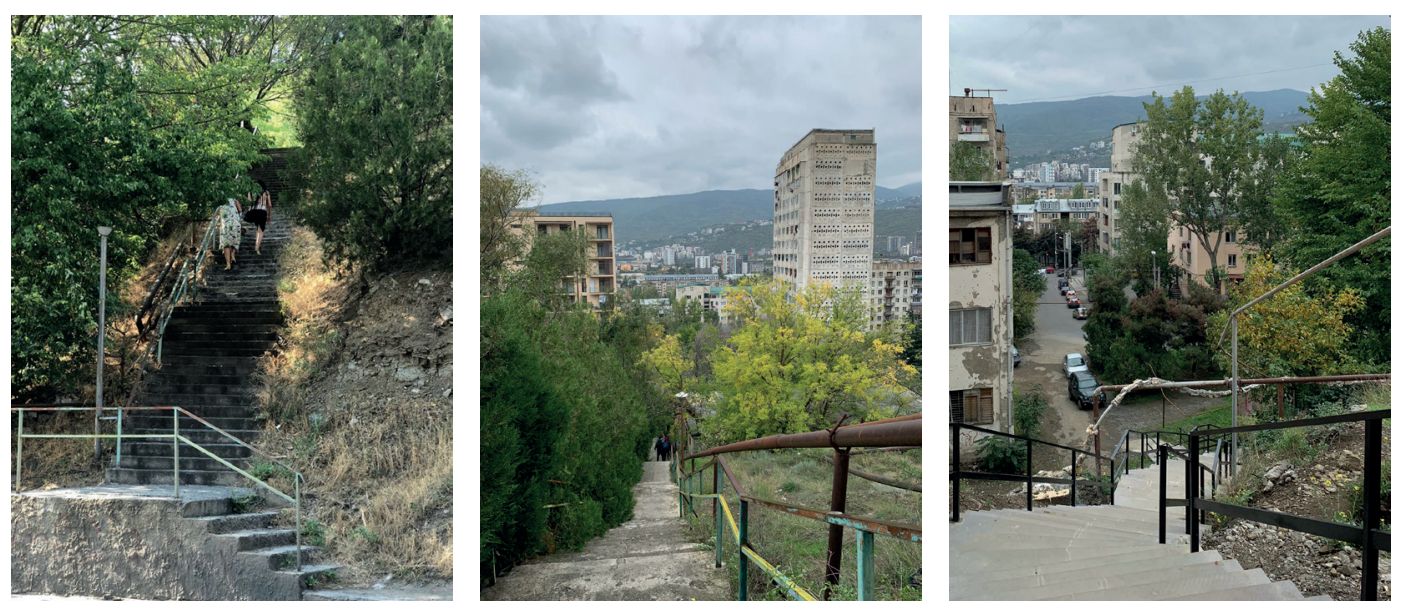

Fom left to right

Fig. 6 -Urban stairs: Access towards the church's terrace, Nutsubidze neighborhood, Tbilisi. 2020 (Author copyrights: NOIA practice)

Fig. 7 -Urban stairs: the beginning of the stairs, Nutsubidze neighborhood, Tbilisi.

2020 (Author copyrights: NOIA practice)

Fig. 8 -Urban stairs: view of Nutsubidze street from the urban stairs, Nutsubidze neighborhood, Tbilisi.

2020 (Author copyrights: NOIA practice) 
$\varangle$
$\vdash$
$\infty$
$\mapsto$
$\triangleright$
$\bullet$
$\bullet$
$\simeq$

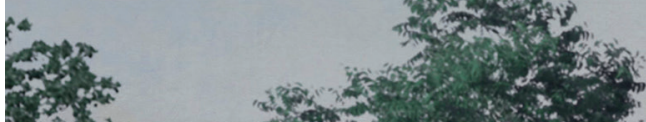

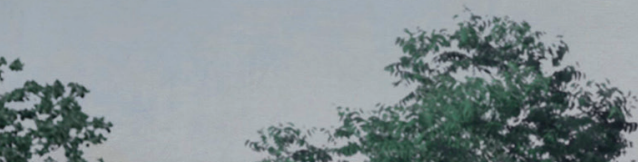

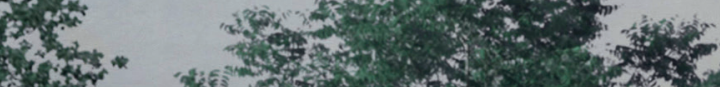

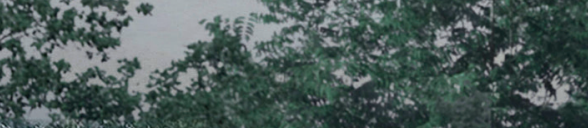

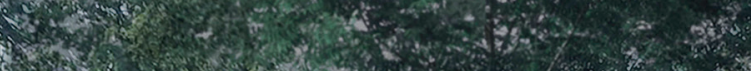
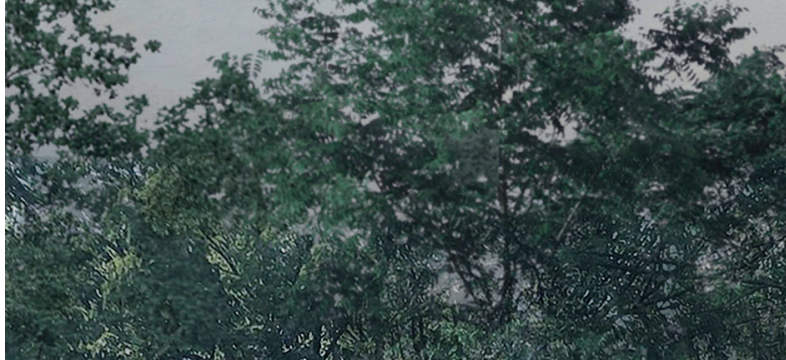

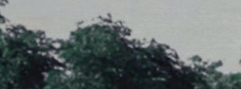

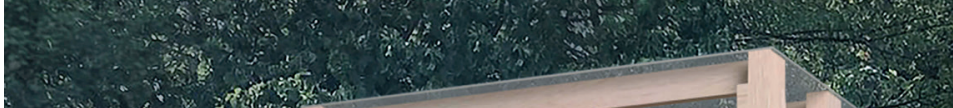

$\sqrt{1.25}$
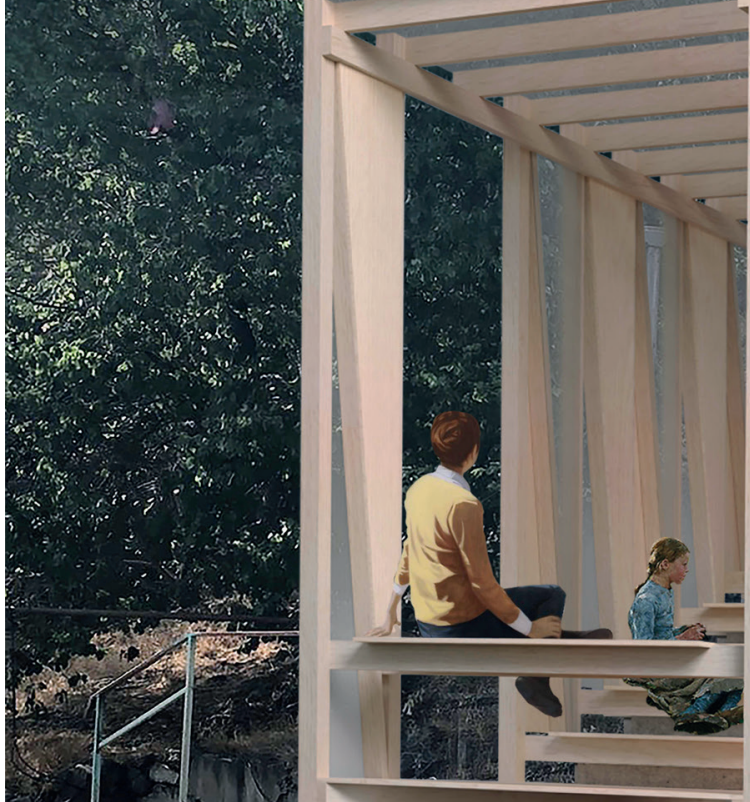

Hin

4

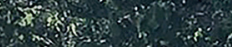

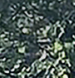

x.

7.7.7.
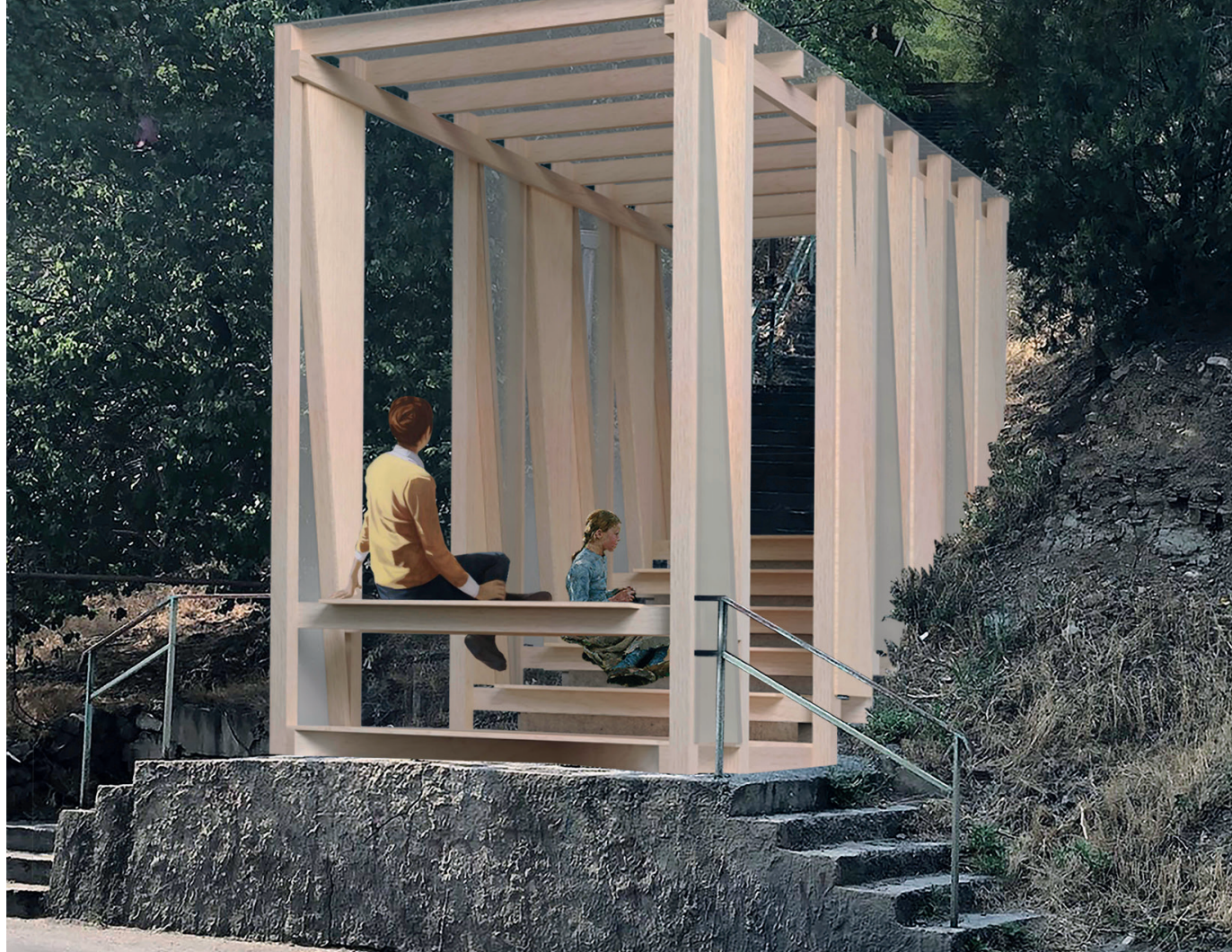

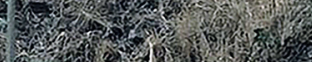

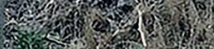
? 


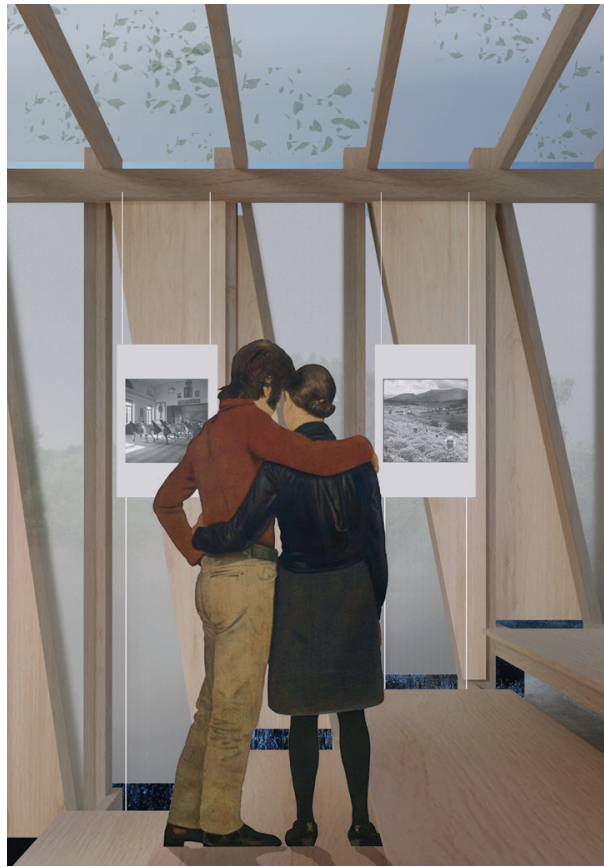

Fig. 10 -Pavilion Common Steps,

a punctual intervention for regenerating urban landscape. View of the architectural elements. 2020 (Author copyrights: NOIA practice)

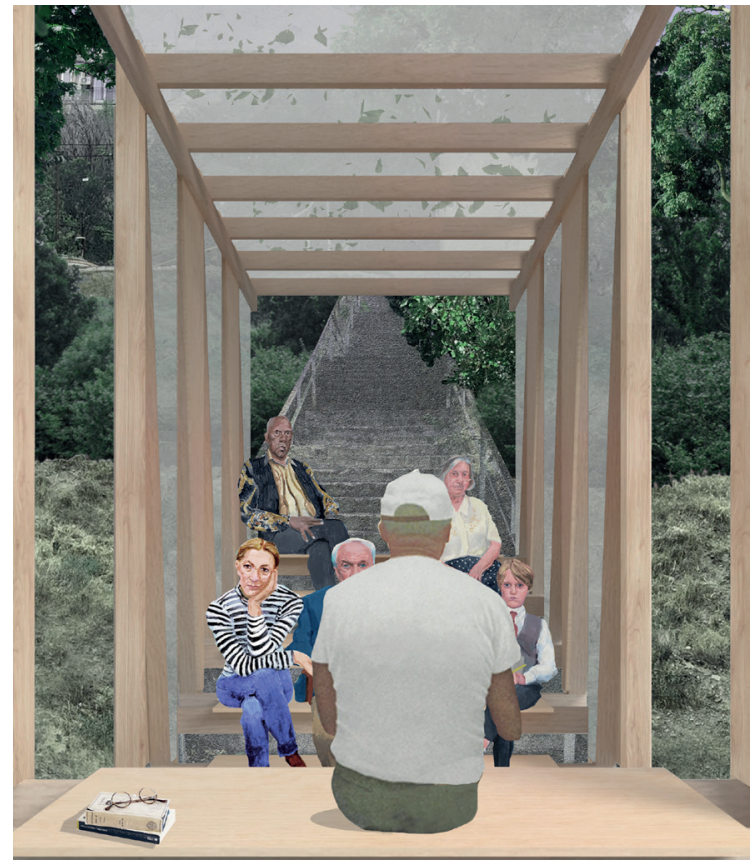

Fig. 11 -Pavilion Common Steps,

a punctual intervention for regenerating urban landscape.

View of the inside space, connection with the landscape and existing infrastructure. 2020 (Author copyrights: NOIA practice) 
By being in a state of abandonment, the site's natural characteristics took over, so the landscape became again dominant.

In this sense, the existing concrete stairway resulted in an opportunity to generate a new hybrid of public space. The pavilion intends to contribute to the current debate on commonness. In particular, the neighbourhood has lost the variety of common space to gather, prominent aspects of the socialist planning in comparison with the modesty of the dwellings. The project suggests a prototype of architecture that could reinforce the presence of public space and its use.

The intervention proposes to transform a small part of the stairs into a tiny pavilion for outdoor events. The structure is based on the module of the stairway steps, and therefore, it recalls the topography of the site. The vertical supports decrease in height as the stairs rise. The rhythm of the structure follows and amplifies the presence of the stairs. The proposal intends to represent in space the faint presence of the stairs, otherwise invisible from the viewpoint of the street.

The infills among supports alternate the presence of opaque wooden elements and semi-transparent elements. This rhythm punctuates the interior space in a sequence of different degrees of transparency 204 of the public space. In particular, semi-transparen- cy is a decisive aspect of contemporary public space. Neither total openness nor introversion reflects the way inhabitants experience urban voids. The possibility of familiarity with parts of the city reinforces the presence of shared situations with the world of F. Nietzsche:

\begin{abstract}
One day, and probably very soon, we need some recognition of what above all is lacking in our big cities: quiet and wide, expansive places for reflection. Places with long, high-ceilinged cloisters for bad or all too sunny weather where no shouting or noise of carriages can reach and where good manners would prohibit even priests from praying aloud /.../ We wish to see ourselves translated into stone and plants, we want to take walks in ourselves when we stroll around these buildings and gardens. (Nietzsche, 1974, p. 226)
\end{abstract}

The pavilion turns the route into an opportunity to host a wide range of activities. Wooden panels lining the treads allow the low steps of the staircase to be transformed into an auditorium for small events. The idea of a space that becomes an area for small events and talk overlaps with ordinary use as a light connecting infrastructure. The elements that support the transparent polycarbonate roof become supports for temporary exhibitions for passers-by. The versatility has been considered an essential element of public space, 
which is never mono-functional or even functional in the strict sense. Its value lies in a certain ambiguity of use and at the same time in the possibility to include the differences. This uncertainty is a requirement for its possibility of success and permanence over time.

The condition of the prototype is emblematic of the relationship between the architectural project and the site. The specificity of the site governs the architecture down to its construction detail, but at the same time determines its universal character. The prototype is a provisional experiment that may allow implementations in another place with similar characteristics and needs. The intervention on a long infrastructure requires the definition of location priorities, but then allows an application of the same idea on a larger scale.

The simplicity of the structure reflects the banality of DIY constructions, in which the intelligence of the whole prevails on the perfection of the individual parts. These features allow for easy construction with unskilled labor or even self-construction. The low-tech approach avoids rapid obsolescence of the work in favor of intuitive and faster transformability. The intervention aims to show the existence of this hidden infrastructure to the local community and to encourage the inhabitants to explore this common public space with new activities.

\section{Conclusion}

In conclusion, architectural design can suggest urban prototypes to reintroduce public space where it tends to disappear. This condition of minute experiment tests the possibility of reversing the abandonment of urban pathways that connect fragments of the city with hilly topography. The attempt to modify the dynamics of a changing context in a punctual manner enables action to be taken in a controlled manner and by small interventions. Thus, it is possible to implement strategies through corrections and adaptations to future needs. The possibility of failure is an integral part of the process and does not involve significant loss of resources or inconvenience to the communities involved. The sharing of common good objectives allows acting through interventions in which the architectural object is a prototype to activate processes and not an immovable infrastructural element. This character of experimentation implies the need to control the process through choices of adaptability, ease of intervention, scarcity of means and urban quality.

Therefore, the involvement of the neighborhood does not represent a rhetorical transition of consensus, but rather a critical element and a long-term goal. The reactivation of alternative urban pathways impacts not only the quality of life and connectivity of a piece of the city but also its identity in the near future. 


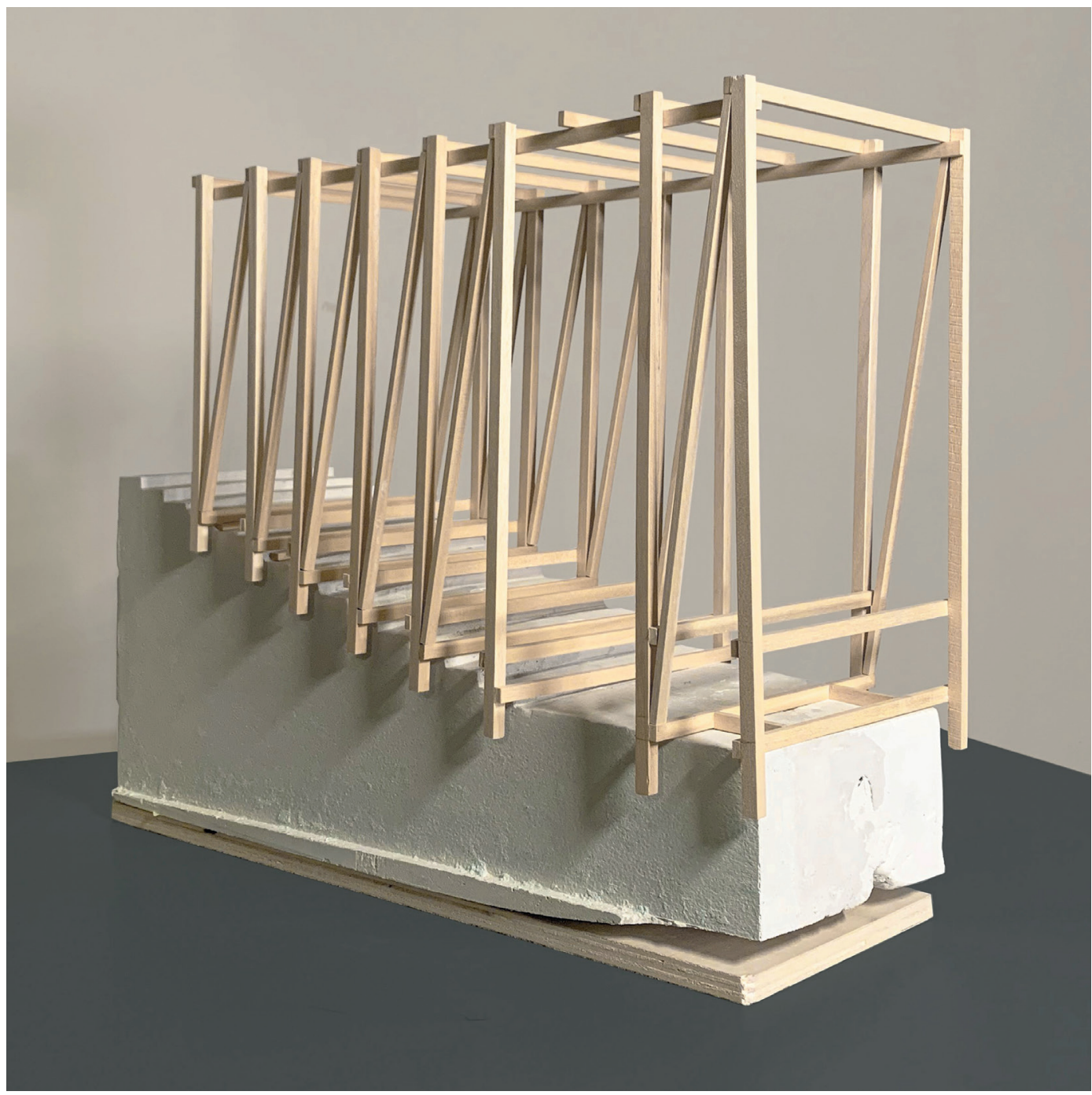

Fom left to right

Fig. 12 - Pavilion Common steps, Physical model for the structural studies. 2020

(Author copyrights: NOIA practice)

Fig. 13 -Pavilion Common steps, Physical model for façade material and transparency studies. 2020

(Author copyrights: NOIA practice)

Fig. 14 - Pavilion Common Steps, Physical model of intervention. 2020

(Author copyrights: NOIA practice) 

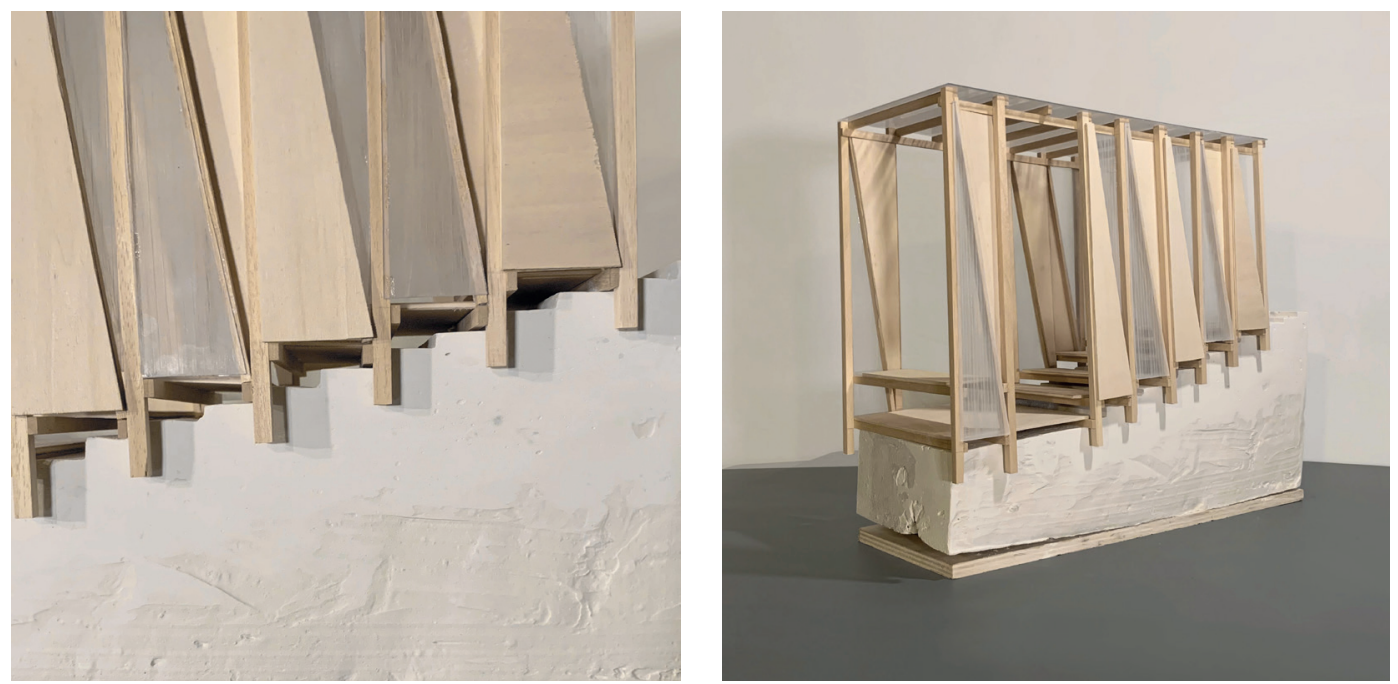

\section{Bibliography}

Amashukeli T. 2017-2018, Georgian Soviet Architecture research; past, present, future, «Tbilisi state academy of arts», n.6. pp. 125-131

Amirejibi K. 2011, First decade of Soviet architecture, «scientific technical journal of Georgian technical university» n.1. pp.6-10

Assunto R. 1994, Il paesaggio e l'estetica, Novecento, Palermo

Augé M. 2007, Tra i confini, Mondadori, Milano

Bakhtadze N. 2019, From "Soviet city" to "cosmopolitan city" architecture as a protagonist for the emergence of new centers of power in south Caucasus, "Civilization researches» n.17 pp.67-77

Bakradze Z. 2013, Urban planning challenges of Tbilisi, «Hot chocolate» n.95. pp.38-47

Burckhardt L. 2019, II falso è autentico. Politica, paesaggio, design, architettura, pianificazione, pedagogia, Quodlibet, Macerata

Careri F. 2006, Walkscapes, Einaudi, Torino

Cicishvili I. 1970, Georgian Soviet architecture during 50 years, Tsodna, Tbilisi

Chubinishvili G. 1941, Georgian Soviet Architecture, "Soviet arts» n.1-2. pp. 72-77

Farinelli F. 2003, Geografia. Un'introduzione ai modelli del mondo, Einaudi, Torino
Jacobs J. 2009, Vita e morte delle grandi città. Saggio sulle metropoli americane, Einaudi, Torino

Kalandazde E. 2012, Particularities of Tbilisi's masterplan in 1939-1955, "scientific technical journal of Georgian technical university" n.2. pp.87-93

Latour B. 1993, We have never been modern, Harvard University Press, Cambridge

Lynch K. 2013, L'immagine della città, Marsilio, Venezia Marini S. 2008, Parasite architecture. Recycling strategies for the city, Quodlibet, Macerata

Nietzsche F. 1974, The Gay Science, Random House, New York

Turri E. 2002, La conoscenza del territorio. Metodologia per un'analisi storico-geografica, Marsilio, Venezia Vogt G., 2015, Landscape as a cabinet of curiosities, Lars Muller Publishers, Zurich 